\title{
THE EFFECT OF ANNUAL TEMPERATURE CHANGES ON SOME IMPORTANT QUALITY TRAITS OF SOYBEAN (GLYCINE $M A X$ L.) GENOTYPES
}

\author{
ARSLAN, $\mathrm{H}$. \\ Field Crops Department, Faculty of Agriculture, Siirt University, Siirt, Turkey \\ (e-mail: huarslan@siirt.edu.tr) \\ (Received $19^{\text {th }}$ Dec 2018; accepted $14^{\text {th }}$ Feb 2019)
}

\begin{abstract}
The study was conducted to investigate the changes in yield, fat and protein ratios and micronutrient concentrations of 9 soybean (Glycine $\max$ L.) lines and 2 standard varieties in semi-arid climatic conditions during soybean production seasons in 2012 and 2013. The experiments were established in a randomized block design with three replicates and were started on 08 May and 06 May in 2012 and 2013, respectively. The plot length was $6 \mathrm{~m}$ and each plot had 4 rows. The interrow spacing was $70 \mathrm{~cm}$ and intra row spacing was $5 \mathrm{~cm}$. Yield, fat and protein ratios and micronutrient concentrations in seeds of soybean varieties/lines were different in two growing seasons. Average temperature during the first growing season was higher than in the second season. The difference in temperature significantly affected the yield, fat and protein ratios and micronutrient concentrations in seeds. $\mathrm{The} \mathrm{Ca}, \mathrm{Cu}, \mathrm{Fe}, \mathrm{K}$, $\mathrm{Mg}, \mathrm{Na} \mathrm{P}$ and $\mathrm{Zn}$ concentrations of soybean seeds in the first year were higher than those obtained in the second year. The differences in nutrient concentrations between years indicated the effects of temperature differences on mineral compositions of seeds in addition to the yield, fat and protein ratios.
\end{abstract}

Keywords: micro element, yield, mineral composition, climate factors, fat and protein ratios

\section{Introduction}

Soybean (Glycine $\max$ L.), which has an important place in human and animal nutrition, is an industrial legume crop with an average of $18-22 \%$ fat, $38-56 \%$ protein in seeds, growing upright, pile rooted, annual, summer crop and grown as main or second crop (Baydar and Erbaş, 2014). Soybean has a nitrogen-fixing symbiotic life with Rhizobium japonicum bacterium, therefore it is an extremely important plant to improve the physical and chemical structures of soils. Soybean is used as soybean oil, soybean sprout and flour in human nutrition as well as in the production of dough products, baby foods, confectionery products, hypoallergenic milk and dairy products, special dietary products, artificial meat products, dry/cold ready food blends. Soybean is used in the production of insecticides as well as to produce wax, soap, candle oil, biodiesel, glue, paper raincoats and plastic materials. Soybean pulp contains 40 to $46 \%$ protein, 1 to $6 \%$ fat, 30 to $31 \%$ carbohydrate and 5 to $6 \%$ cellulose, and is used in animal feeding (Singh and Shivakumar, 2010). Studies on soybean demonstrated that soybean is protective against cancer and individuals fed with soya and soy products are less likely to develop different types of cancers. Soybean has also positive effects on prevention of many other diseases (menopause, cholesterol, osteoporosis, cardiovascular and chronic diseases - coronary heart diseases) (Uesugi et al., 2002; Lovati et al., 1987; Messina, 1999; Xiao, 2008; Brouns, 2002).

Soybean is the most widely produced oilseed plant in the world (USDA, 2018). Although $30{ }^{\circ} \mathrm{C}$ temperature is considered optimum for dry matter accumulation of soybean plants (Raper and Kramer, 1987), soybean is grown in regions of temperate and tropical climate with various environmental conditions (Hasanuzzaman et al., 2016). According to the oldest records known in China, soybean had been known by mankind 
since $11^{\text {th }}$ century or a little earlier time (Hymowitz and Shurtleff, 2005). Soybean, originated from China, was brought from the old world to the new world in the middle of the $17^{\text {th }}$ century, and began to gain importance all over the world in the early $20^{\text {th }}$ century. The introduction of soybean to Turkey coincides to the World War I (Arioglu, 2007). The soybean in 2016 has been cultivated on approximately 121 million ha land throughout the world, and 335 million tons of soybean have been produced (FAOSTAT, 2017). Soybean consumption per person in the world is $40.64 \mathrm{~kg} \mathrm{year}^{-1}$ considering that entire soybean produced in the world have been consumed by human being. However, a large part of the produced soybean is used in animal feeding. In Turkey, 150.000 tons of soybean have been produced in 34.000 ha land. Soybean ranks $4^{\text {th }}$ with $1,073,757$ tons among imported agricultural products by Turkey and processed soybean products ranks the $3^{\text {rd }}$ with 1.0867.4 million tons (FAOSTAT, 2017).

Studies on cultivation and adaptation of soybean, which is important as a raw material in human nutrition and in the industry, are also of great importance. Studies indicated that climate, soil and other environmental factors have significant influences on yield and quality traits of soybean (Jumrani and Bhatia, 2018; Shah and Paulsen, 2003; Hasanuzzaman et al., 2016). This study was conducted to determine the yields, fat and protein ratios and micronutrient contents of different soybean genotypes grown under semi-arid climatic conditions and to investigate the relationships among soybean characteristics determined.

\section{Materials and methods}

The study was conducted during the main crop soybean production season in 2012 and 2013 using 2 standard soybean varieties (Ataem-7 and Türksoy) and 9 advanced soybean lines $(6,11,13,17,24,27,834,1021$ and 1022) as plant materials. The pedigrees of lines were given in the Table 1 .

Table 1. Pedigrees of lines used in the study

\begin{tabular}{c|c|c}
\hline Line number & o & 更 \\
\hline 6 & Wayne & Keller \\
11 & Spancer & SGI 1308 \\
13 & Williams & Keller \\
17 & Spancer & SGI 1308 \\
24 & Williams & Keller \\
27 & Williams & Keller \\
834 & Williams & Keller \\
1021 & Spancer & SGI 1308 \\
1022 & Spancer & SGI 1308 \\
\hline
\end{tabular}

The field experiments were carried out in Gündaş research station of GAP (Southeast Anatolian Irrigation Project) Agricultural Research Institute during soybean growing seasons of 2012 and 2013 in different plots. Gündaş station is located at 36044' 05.22 N and 38048 ' 49.76 E within the borders of Akçakale town of Sanliurfa province, Turkey (Fig. 1). The summers are dry and hot, and the winters are relatively warm. The average 
temperature in July and August is $40{ }^{\circ} \mathrm{C}$, while in some nights the temperature goes above $30{ }^{\circ} \mathrm{C}$ (Turkish State Meteorological Service, 2017).

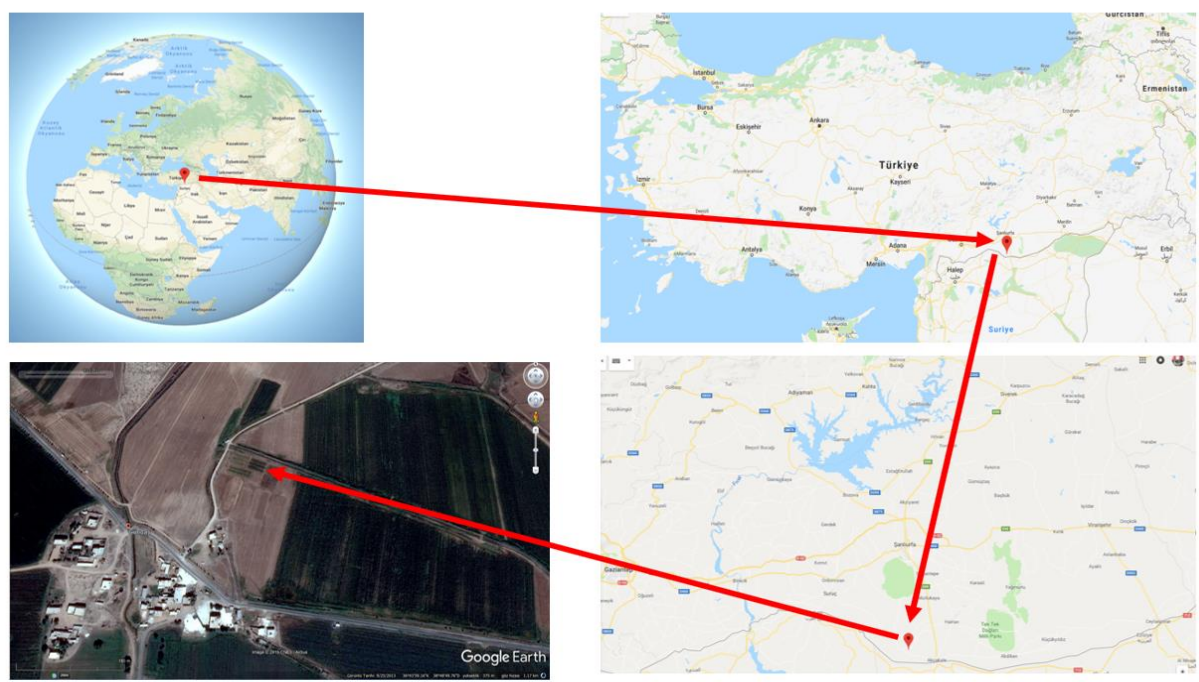

Figure 1. Location of experimental site within GAP Agricultural Research Institute

The experiments were conducted in 2012 and 2013 at the same locations. Particle size distribution of soils were determined by water saturation method (Richards, 1954). Soil reaction $(\mathrm{pH})$ was measured in saturation paste with a $\mathrm{pH}$ meter (Richards, 1954). Calcium carbonate content of soils was analyzed by using Scheibler calcimeter method (Çağlar, 1949), plant available phosphorus content was determined according to Olsen method (Olsen et al., 1954). Available potassium was extracted using $1 \mathrm{~N}$ ammonium acetate $(\mathrm{pH}=7.0)$ solution (Pratt, 1965). Organic matter content of soils was determined by using modified Walkey-Black wet combustion method (Nelson and Sommers, 1982). Boron concentration of soils was determined by azomethine- $\mathrm{H}$ method (John et al., 1975). Micronutrient concentrations were extracted using diethylene triamine penta acetic acid (DTPA) and determined by an atomic adsorption spectrophotometer (Perkin Elmer Analyst 800) (Lindsay and Norvell, 1978). The results were presented in Tables 2 and 3.

Table 2. Soil characteristics of experimental sites

\begin{tabular}{|c|c|c|c|c|c|c|c|}
\hline Years & $\begin{array}{c}\text { Water } \\
\text { saturation }(\%)\end{array}$ & pH & $\begin{array}{c}\mathrm{EC} \\
\left(\mathrm{dS} \mathbf{~ m}^{-1}\right)\end{array}$ & $\begin{array}{c}\mathrm{CaCO}_{3} \\
(\%)\end{array}$ & $\begin{array}{c}\mathbf{P}_{2} \mathrm{O}_{5} \\
\left(\mathrm{~kg} \mathrm{ha}^{-1}\right)\end{array}$ & $\begin{array}{c}\mathrm{K}_{2} \mathrm{O} \\
\left(\mathrm{kg} \mathrm{ha}^{-1}\right)\end{array}$ & $\begin{array}{c}\text { Organic } \\
\text { matter }(\%)\end{array}$ \\
\hline 2012 & 64 & 7.53 & 0.51 & 26.6 & 56 & 2490 & 2.32 \\
\hline 2013 & 69 & 7.47 & 0.89 & 24.3 & 51.9 & 3000 & 2.45 \\
\hline
\end{tabular}

Table 3. Micronutrient concentrations of soils in experimental sites

\begin{tabular}{c|c|c|c|c|c|c|c|c|c|c}
\hline \multirow{2}{*}{ Years } & $\mathbf{C u}$ & Fe & Mn & Zn & Ca & Mg & Na & K & B \\
\cline { 2 - 10 } & \multicolumn{9}{|c|}{$\left(\mathbf{m g ~ k g}^{-1}\right)$} \\
\hline 2012 & 1.461 & 9.386 & 26.79 & 0.508 & 7811 & 464.9 & 79.27 & 884.8 & 1.041 \\
\hline 2013 & 1.915 & 9.572 & 15.3 & 0.641 & 7383 & 942.8 & 169.8 & 807.7 & 1.693 \\
\hline
\end{tabular}


Soils were neutral in reaction (Ülgen and Yurtsever, 1995), non-saline (Richards, 1954), highly calcareous, low in phosphorus, high in potassium and moderate in organic matter content (Ülgen and Yurtsever, 1995). Soil water saturation (\%), pH level, salinity $\left(\mathrm{EC} \mathrm{dS} \mathrm{m} \mathrm{m}^{-1}\right)$, calcium carbonate $(\%)$, plant available phosphorus $\left(\mathrm{P}, \mathrm{kg} \mathrm{ha}^{-1}\right)$, available potassium $\left(\mathrm{K}, \mathrm{kg} \mathrm{ha}^{-1}\right)$ and organic matter content of soils in experimental sites were not significantly different from each other (Table 2).

Concentrations of soil $\mathrm{Cu}, \mathrm{Mg}, \mathrm{Na}$ and $\mathrm{B}$ in the second year were significantly higher than that of the first year, while $\mathrm{Fe}$ and $\mathrm{Zn}$ concentrations were slightly higher in the second year. In contrast, $\mathrm{Mn}$ and $\mathrm{Ca}$ concentrations of soils in the second year were lower compared to that of the first year. Soils contained sufficient amount of $\mathrm{Cu}, \mathrm{Fe}$ and Mn however, $\mathrm{Zn}$ concentration of soils was at critical level (Lindsay and Norvell, 1978). Boron concentration of soils was sufficient (Sürücü et al., 2018).

The average temperatures in June, July and August of 2012 which are the vegetative and generative development periods of soybean were higher compared to the temperatures in 2013 (Table 4).

Table 4. Long-term and 2012-2013 average climate data for Akçakale Town of Şanliurfa Province (Turkish State Meteorological Service, 2017)

\begin{tabular}{|c|c|c|c|c|c|c|}
\hline Months & Years & $\begin{array}{c}\text { Monthly } \\
\text { average min. } \\
\text { temp. }\left({ }^{\circ} \mathrm{C}\right)\end{array}$ & $\begin{array}{c}\text { Monthly } \\
\text { average max. } \\
\text { temp. }\left({ }^{\circ} \mathrm{C}\right)\end{array}$ & $\begin{array}{c}\text { Monthly } \\
\text { average } \\
\text { temp. }\left({ }^{\circ} \mathrm{C}\right)\end{array}$ & $\begin{array}{c}\text { Monthly } \\
\text { average relative } \\
\text { humidity }(\%)\end{array}$ & $\begin{array}{l}\text { Monthly total } \\
\text { precipitation } \\
\left(\mathrm{mm}=\mathrm{kg} \mathrm{m}^{-2}\right)\end{array}$ \\
\hline \multirow{3}{*}{ April } & 2012 & 10.70 & 26.90 & 18.60 & 48.30 & 44.80 \\
\hline & 2013 & 10.10 & 26.00 & 17.80 & 53.00 & 9.20 \\
\hline & LTA* & 8.19 & 23.86 & 16.34 & 67.64 & 25.96 \\
\hline \multirow{3}{*}{ May } & 2012 & 14.60 & 29.80 & 22.00 & 49.80 & 43.20 \\
\hline & 2013 & 15.60 & 31.60 & 23.30 & 47.20 & 43.40 \\
\hline & LTA* & 13.00 & 30.20 & 22.56 & 56.42 & 22.82 \\
\hline \multirow{3}{*}{ June } & 2012 & 20.80 & 38.20 & 30.10 & 26.00 & 4.60 \\
\hline & 2013 & 19.60 & 36.80 & 28.70 & 28.90 & 0.20 \\
\hline & LTA* & 17.46 & 36.01 & 28.19 & 47.34 & 3.12 \\
\hline \multirow{3}{*}{ July } & 2012 & 23.10 & 40.40 & 32.10 & 26.30 & 0.00 \\
\hline & 2013 & 21.90 & 39.60 & 31.30 & 27.20 & 0.00 \\
\hline & LTA* & 20.73 & 39.90 & 31.41 & 46.23 & 2.89 \\
\hline \multirow{3}{*}{ August } & 2012 & 21.90 & 39.80 & 31.10 & 32.70 & 0.00 \\
\hline & 2013 & 20.90 & 39.40 & 30.40 & 30.60 & 0.00 \\
\hline & LTA* & 19.87 & 38.99 & 30.43 & 48.37 & 0.00 \\
\hline \multirow{3}{*}{ September } & 2012 & 17.80 & 36.30 & 26.80 & 37.80 & 3.80 \\
\hline & 2013 & 16.50 & 33.70 & 25.10 & 38.70 & 0.00 \\
\hline & LTA* & 15.28 & 34.44 & 25.39 & 52.11 & 0.55 \\
\hline \multirow{3}{*}{ October } & 2012 & 14.10 & 28.40 & 20.80 & 54.80 & 35.20 \\
\hline & 2013 & 10.00 & 26.90 & 18.40 & 33.50 & 0.40 \\
\hline & LTA* & 11.28 & 27.98 & 19.74 & 59.09 & 21.41 \\
\hline
\end{tabular}

*LTA: long-term average (1927-2013)

The experiments were established in a randomized block design with three replicates on May 08 and May 06 in 2012 and 2013, respectively. The plot length was $6 \mathrm{~m}$ and 
each plot had 4 rows. The interrow spacing was $70 \mathrm{~cm}$ and intra row spacing was $5 \mathrm{~cm}$. Irrigation, hoeing and all other maintenance works of experimental sites have been carried out as needed. Plants were harvested between October 01 and 10, 2012 in the first year and October 05 and 10, 2013 in the second year. Rhizobium japonicum bacterial inoculation could not be carried out during planting. Soybean seed yield, fat ratio, protein ratio and seed micro nutrient concentrations which have significant effect on soybean seed quality (Kacar and İnal, 2008) were determined.

The data obtained were subjected to analyses of variance using JUMP statistic software package and average values for each of traits were grouped according to LSD test. The correlation test was also conducted to determine the relationship between the characteristics examined. The correlation test was also performed using JUMP statistical software. Since the study was not carried out under controlled climatic conditions, the effects of environmental factors were not analyzed.

\section{Results}

Average yield $\left(\mathrm{kg} \mathrm{ha}^{-1}\right)$, fat ratio $(\%)$ and protein ratio $(\%)$ of varieties/lines were given in Table 5. Yield values $\left(\mathrm{kg} \mathrm{ha}^{-1}\right)$ of different soybean varieties/lines in 2012 were significantly different $(\mathrm{p}<0.01)$, while fat and protein ratios were not significantly different. Yield of varieties/lines varied between 2044.30 (line 11) and $2950.00 \mathrm{~kg} \mathrm{ha}^{-1}$ (line 6). The highest fat ratio was obtained with line 1022 as $18.18 \%$, while the lowest fat ratio $(15.44 \%)$ was obtained with line 13 . The highest protein ratio $(37.46 \%)$ was obtained with line 13 and the lowest protein ratio (34.73\%) was with line 24. Yield and fat ratio obtained for soybean varieties/lines in 2013 were significantly different $(\mathrm{p}<0.01)$, while protein ratio values did not significantly change among soybean varieties/lines. Yield values of varieties/lines in 2013 ranged from $2892.90 \mathrm{~kg} \mathrm{ha}^{-1}$ (line 24) to $4464.60 \mathrm{~kg} \mathrm{ha}^{-1}$ (line 11). The fat ratio of varieties/lines varied between $18.49 \%$ (line 13) and $22.56 \%$ (line 1021). The highest protein ratio (37.43\%) was obtained with line 13 and the lowest ratio was $(34.30 \%)$ with line 1021.

Average soybean seed $\mathrm{B}, \mathrm{Ca}, \mathrm{Cu}, \mathrm{Fe}, \mathrm{K}, \mathrm{Mg}, \mathrm{Mn}, \mathrm{P}$ and $\mathrm{Zn}$ concentrations in 2012 were significantly different $(\mathrm{p}<0.05)$ among varieties (Table 6). In contrast, $\mathrm{Na}$ concentration of seeds was not significantly different. The concentrations of $\mathrm{B}, \mathrm{Ca}, \mathrm{Cu}$, $\mathrm{Fe}, \mathrm{Mg}, \mathrm{Mn}, \mathrm{P}$ and $\mathrm{Na}$ in 2013 were not significantly different, while $\mathrm{Zn}$ was significantly different $(\mathrm{p}<0.01)$. The differences in $\mathrm{Zn}$ response is probably resulted from the differences in genetic structures of the genotypes. Boron concentration in seeds of varieties ranged from 2.11 to $10.04 \mathrm{mg} \mathrm{kg}^{-1}$ in 2012 . Boron concentration of line 1021 was higher than the rest of the varieties/lines. Calcium concentration of varieties was between 1800.33 and $2601.00 \mathrm{mg} \mathrm{kg}^{-1}$. Calcium concentrations of line 1021 and Ataem-7 variety were similar to each other and higher than other lines/varieties investigated. Cupper concentration of lines/varieties ranged from 19.80 to $26.58 \mathrm{mg} \mathrm{kg}^{-}$ ${ }^{1}$. Cupper concentrations of Türksoy variety and lines 27 and 1021 were similar to each other and higher compared to the other lines/varieties. Average seed Fe content was $65.81 \mathrm{mg} \mathrm{kg}^{-1}$ and the highest Fe content was obtained with line 1021. Potassium concentration in seeds of lines/varieties varied between 33798.33 and $38106.67 \mathrm{mg} \mathrm{kg}^{-1}$ and the highest $\mathrm{K}$ concentration was obtained with line 1021. Magnesium concentration in seeds of lines/varieties ranged from 1598.33 to $1901.67 \mathrm{mg} \mathrm{kg}^{-1}$ and line 1022 had the highest $\mathrm{Mg}$ concentration. Manganese concentration in seeds varied between 26.26 and $51.41 \mathrm{mg} \mathrm{kg}^{-1}$ and $\mathrm{Mn}$ concentrations of lines 1022 and 6 were similar to each other and 
higher than the rest of the lines/varieties. Sodium concentration of lines/varieties ranged from 79.49 to $119.63 \mathrm{mg} \mathrm{kg}^{-1}$. The highest $\mathrm{Na}$ concentration was obtained with line 13 . Phosphorus and $\mathrm{Zn}$ concentrations of lines/varieties ranged from 3627.667 to $4825.33 \mathrm{mg} \mathrm{kg}^{-1}$ and from 29.74 to $46.93 \mathrm{mg} \mathrm{kg}^{-1}$, respectively Phosphorus concentration of line 13 and $\mathrm{Zn}$ concentration of line 834 were higher compared to the other lines/varieties investigated. Boron concentration of all lines/varieties in 2013 increased, while $\mathrm{Ca}, \mathrm{Cu}, \mathrm{K}, \mathrm{Mg}, \mathrm{Na}$ and $\mathrm{P}$ concentrations decreased relative to that of 2012. The Fe concentration of Gapsoy-16 increased in the second year, while decreased in all other lines/varieties. The Mn concentration of lines 1022, 6 and 1021 decreased relative to the first year, whereas Mn concentration of other lines/varieties in the second year increased. The $\mathrm{Zn}$ concentration of lines 1022 and 24 increased in the second year, while decreased in other lines/varieties.

Table 5. Average values and groups of traits investigated for different soybean varieties/lines in 2012 and 2013

\begin{tabular}{|c|c|c|c|c|c|c|}
\hline Years & Varieties/lines & Yield** (kg & $\left.\mathbf{h a}^{-1}\right)$ & Oil ra & $* *(\%)$ & Protein rate (\%) \\
\hline \multirow{14}{*}{2012} & 11 & 2950.00 & $\mathrm{a}$ & \multicolumn{2}{|c|}{15.89} & 36.97 \\
\hline & Ataem-7 & 2900.50 & $\mathrm{a}$ & \multicolumn{2}{|c|}{15.83} & 35.68 \\
\hline & 13 & 2760.50 & $\mathrm{a}$ & \multicolumn{2}{|c|}{15.44} & 37.46 \\
\hline & 834 & 2560.50 & $\mathrm{~b}$ & \multicolumn{2}{|c|}{17.52} & 35.39 \\
\hline & 27 & 2552.90 & $\mathrm{~b}$ & \multicolumn{2}{|c|}{18.00} & 34.56 \\
\hline & 17 & 2500.00 & $\mathrm{~b}$ & \multicolumn{2}{|c|}{17.67} & 36.48 \\
\hline & 1022 & 2433.30 & $\mathrm{~b}$ & \multicolumn{2}{|c|}{18.18} & 35.78 \\
\hline & 24 & 2413.80 & $\mathrm{~b}$ & \multicolumn{2}{|c|}{16.18} & 34.73 \\
\hline & Türksoy & 2150.00 & $\mathrm{c}$ & \multicolumn{2}{|c|}{17.20} & 35.28 \\
\hline & 1021 & 2145.70 & $\mathrm{c}$ & \multicolumn{2}{|c|}{16.85} & 37.22 \\
\hline & 6 & 2044.30 & $\mathrm{c}$ & \multicolumn{2}{|c|}{17.36} & 37.00 \\
\hline & Average & 2492.00 & & \multicolumn{2}{|c|}{16.92} & 36.05 \\
\hline & $\mathrm{CV}(\%)$ & 4.54 & & \multicolumn{2}{|c|}{7.09} & 5.70 \\
\hline & LSD & 192.70 & & \multicolumn{2}{|c|}{ NS } & NS \\
\hline \multirow{14}{*}{2013} & 11 & 4464.30 & $\mathrm{a}$ & 20.80 & $\mathrm{ab}$ & 35.60 \\
\hline & 13 & 4339.30 & $\mathrm{ab}$ & 18.49 & $\mathrm{c}$ & 37.43 \\
\hline & 27 & 4214.30 & $\mathrm{bc}$ & 21.21 & $\mathrm{ab}$ & 35.61 \\
\hline & 1021 & 4071.40 & $\mathrm{~cd}$ & 22.56 & $\mathrm{a}$ & 34.30 \\
\hline & Ataem-7 & 4000.00 & $\mathrm{~cd}$ & 19.73 & $\mathrm{bc}$ & 37.15 \\
\hline & 1022 & 3982.10 & $\mathrm{~d}$ & 21.87 & $\mathrm{a}$ & 35.31 \\
\hline & 834 & 3928.60 & $\mathrm{~d}$ & 21.13 & $a b$ & 35.27 \\
\hline & Türksoy & 3928.60 & $\mathrm{~d}$ & 21.90 & $\mathrm{a}$ & 35.33 \\
\hline & 17 & 3875.00 & de & 20.80 & $a b$ & 35.03 \\
\hline & 6 & 3678.60 & $\mathrm{e}$ & 21.02 & $a b$ & 35.66 \\
\hline & 24 & 2892.90 & $\mathrm{f}$ & 19.46 & $\mathrm{bc}$ & 36.29 \\
\hline & Average & 3943.20 & & 20.82 & & 35.73 \\
\hline & CV (\%) & 3.38 & & 5.08 & & 4.81 \\
\hline & LSD & 22.70 & & 1.80 & & NS \\
\hline
\end{tabular}

**Means followed by different letters are significantly different to each other $\mathrm{P}<0.05$ NS: non-significant; CV: coefficient of variation; LSD: least significant differences 
Table 6. Microelement contents of soybean varieties/lines according to years in grain

\begin{tabular}{|c|c|c|c|c|c|c|c|c|c|c|c|c|}
\hline \multirow{2}{*}{ Years } & \multirow{2}{*}{ Varieties/lines } & B** & $\mathrm{Ca}^{* *}$ & $\mathrm{Cu}^{* * *}$ & $\mathrm{Fe}^{* * *}$ & $\mathbf{K}^{* * *}$ & Mg** & Mn** & $\mathbf{N a}$ & $\mathbf{P}^{* * *}$ & \multicolumn{2}{|c|}{$\mathbf{Z n}^{* * *}$} \\
\hline & & \multicolumn{11}{|c|}{$\left(\mathrm{mg} \mathrm{kg}^{-1}\right)$} \\
\hline \multirow{14}{*}{2012} & 1022 & 2.11 & 2174.67 & 23.64 & $78.63 \quad \mathrm{~b}$ & 33798.33 & $1901.67 \quad \mathrm{a}$ & 49.89 & 96.18 & $4426.00 \quad \mathrm{c}$ & 37.87 & $\mathrm{~g}$ \\
\hline & 27 & 9.23 & 2170.33 & 26.58 & 71.26 & 38106.67 & $1749.33 \mathrm{c}$ & 33.75 & 89.76 & $4683.67 \quad b$ & 43.70 & $\mathrm{~b}$ \\
\hline & 17 & 3.61 & 1800.33 & 21.81 & 64.55 & 36820.00 & $1662.33 \mathrm{de}$ & 26.26 & 83.16 & $4424.00 \quad \mathrm{c}$ & 41.20 & de \\
\hline & 834 & 5.96 & 1923.67 & 24.06 & 54.33 & 37306.67 & $1802.00 \quad \mathrm{~b}$ & 32.78 & 79.99 & $4250.33 \mathrm{~d}$ & 46.44 & $\mathrm{a}$ \\
\hline & 6 & 4.82 & 1870.33 def & 21.18 & $63.67 \mathrm{~d}$ & 35426.67 & $1708.00 \mathrm{~cd}$ & $51.41 \quad \mathrm{a}$ & 99.34 & $3627.67 \quad \mathrm{f}$ & 29.74 & $\mathrm{~h}$ \\
\hline & Türksoy & 6.08 & $2356.33 \mathrm{~b}$ & 25.72 & $69.70 \quad \mathrm{c}$ & 33983.33 & $1726.67 \mathrm{c}$ & 32.72 & 106.54 & $4684.00 \quad \mathrm{~b}$ & 43.22 & $\mathrm{bc}$ \\
\hline & 1021 & 3.52 & 2601.00 & 25.93 & $85.47 \quad \mathrm{a}$ & 36256.67 & $1799.33 \mathrm{~b}$ & 41.63 & 79.49 & $4732.00 \quad \mathrm{ab}$ & 42.12 & $\mathrm{~cd}$ \\
\hline & 24 & 8.53 & 1842.67 def & 22.63 & $60.21 \mathrm{de}$ & 36220.00 & 1617.00 ef & 29.84 & 93.29 & $4191.67 \mathrm{~d}$ & 44.25 & $\mathrm{~b}$ \\
\hline & Gapsoy-16 & 6.30 & 1829.00 ef & 19.80 & $46.92 \mathrm{~g}$ & 36266.67 & $1598.33 \mathrm{f}$ & 41.63 & 103.85 & $3896.67 \mathrm{e}$ & 39.01 & $\mathrm{fg}$ \\
\hline & Ataem-7 & 5.24 & $2540.67 \quad \mathrm{a}$ & 21.13 & 58.50 ef & 37276.67 & $1665.33 \mathrm{~d}$ & 39.52 & 95.01 & $4140.33 \mathrm{~d}$ & 40.13 & ef \\
\hline & 13 & $10.04 \quad \mathrm{a}$ & $1892.00 \mathrm{de}$ & $23.90 \quad b$ & $73.75 \mathrm{c}$ & $37370.00 \quad \mathrm{ab}$ & $1748.33 \mathrm{c}$ & $33.63 \mathrm{~d}$ & 119.63 & $4825.33 \quad \mathrm{a}$ & 46.93 & $\mathrm{a}$ \\
\hline & Average & 5.95 & 2091 & 23.31 & 65.81 & 36257.42 & 1725.30 & 37.57 & 95.11 & 4352.88 & 41.3 & \\
\hline & $\mathrm{CV}$ & 34.46 & 1.85 & 2.65 & 4.31 & 1.28 & 1.56 & 2.82 & 18.56 & 1.87 & 2.14 & \\
\hline & LSD & 3.49 & 88.89 & 1.05 & 4.83 & 793.05 & 45.89 & 1.80 & $\mathrm{~ns}$ & 138.70 & 1.50 & \\
\hline \multirow{16}{*}{2013} & \multirow{2}{*}{ Varieties/lines } & \multicolumn{2}{|r|}{$\mathbf{C a}$} & $\mathrm{Cu}$ & $\mathbf{F e}$ & $\mathbf{K}$ & Mg & Mn & $\mathrm{Na}$ & $\mathbf{P}$ & $\mathbf{Z n}$ & \\
\hline & & \multicolumn{11}{|c|}{$\left(\mathrm{mg} \mathrm{kg}^{-1}\right)$} \\
\hline & 1022 & 50.39 & 1478.33 & 18.35 & 50.63 & 16796.67 & 1475.00 & 42.07 & 28.91 & 3054.00 & 37.98 & $\mathrm{bc}$ \\
\hline & 27 & 49.32 & 1541.00 & 18.25 & 51.07 & 17170.00 & 1502.67 & 40.87 & 34.47 & 3108.33 & 36.61 & $\mathrm{bc}$ \\
\hline & 17 & 48.94 & 1673.67 & 19.77 & 50.94 & 17180.00 & 1600.33 & 39.47 & 34.04 & 3148.00 & 38.98 & $\mathrm{bc}$ \\
\hline & 834 & 50.00 & 1632.33 & 19.56 & 50.58 & 16796.67 & 1589.67 & 43.10 & 29.73 & 3064.33 & 39.99 & $\mathrm{bc}$ \\
\hline & 6 & 50.12 & 1717.00 & 20.11 & 53.69 & 18436.67 & 1667.67 & 43.93 & 29.28 & 3325.33 & 40.77 & $\mathrm{~b}$ \\
\hline & Türksoy & 51.44 & 1544.33 & 19.99 & 50.08 & 17660.00 & 1673.33 & 40.76 & 27.81 & 3203.33 & 40.05 & $\mathrm{bc}$ \\
\hline & 1021 & 53.33 & 1625.00 & 19.18 & 49.83 & 17726.67 & 1604.67 & 40.88 & 33.76 & 3268.00 & 37.17 & $\mathrm{bc}$ \\
\hline & 24 & 50.47 & 1725.67 & 18.87 & 56.72 & 18056.67 & 1609.33 & 42.53 & 33.07 & 3483.33 & 46.12 & $\mathrm{a}$ \\
\hline & Gapsoy-16 & 54.11 & 1669.67 & 19.73 & 55.18 & 18970.00 & 1661.00 & 45.47 & 27.03 & 3507.67 & 36.37 & $\mathrm{c}$ \\
\hline & Ataem-7 & 54.57 & 1678.33 & 19.22 & 55.50 & 17900.00 & 1666.00 & 40.72 & 31.67 & 3409.67 & 39.31 & $\mathrm{bc}$ \\
\hline & 13 & 51.26 & 1781.33 & 21.11 & 59.68 & 17753.33 & 1666.33 & 42.94 & 29.19 & 3308.33 & 37.55 & $\mathrm{bc}$ \\
\hline & Average & 51.27 & 1642.42 & 19.47 & 53.08 & 17676.97 & 1610.55 & 42.07 & 30.82 & 3261.85 & 39.1 & \\
\hline & $\mathrm{CV}$ & 5.98 & 10.38 & 8.15 & 9.60 & 5.06 & 8.00 & 9.85 & 13.94 & 7.37 & 6.23 & \\
\hline & LSD & $\mathrm{ns}$ & $\mathrm{ns}$ & $\mathrm{ns}$ & $\mathrm{ns}$ & $\mathrm{ns}$ & $\mathrm{ns}$ & $\mathrm{ns}$ & $\mathrm{ns}$ & $\mathrm{ns}$ & 4.16 & \\
\hline
\end{tabular}

**Means followed by different letters are significantly different to each other $\mathrm{P}<0.05$

ns: not significant; $\mathrm{CV}$ : coefficient of variation 


\section{Relationship between grain yield and micronutrient concentrations of lines/varieties}

Correlation analysis was conducted to reveal the relationship between yield, fat ratio, protein ratio and seed micronutrient contents. In the first year, soybean yield had a significant positive correlation with $\mathrm{K}$ concentration and negative relationship with $\mathrm{Cu}$ and Fe concentrations. The relationship can be attributed to plant growth and explained by the dilution effects of plant nutrients. Although not statistically significant, yield had negative relationships with fat ratio, protein ratio, $\mathrm{Ca}, \mathrm{Mg}, \mathrm{Mn}$ and $\mathrm{P}$ concentrations, while yield had positive relationships with $\mathrm{B}, \mathrm{Na}$ and $\mathrm{Zn}$ concentrations (Table 7). In the second year, yield had non-significant negative relationship with $\mathrm{Ca}, \mathrm{Fe}, \mathrm{Na}$ and $\mathrm{P}$ concentrations while yield had positive relationship with fat ratio, protein ratio, $\mathrm{B}, \mathrm{Cu}$, $\mathrm{K}, \mathrm{Mg}$ and $\mathrm{Mn}$ concentrations. Yield had significant negative relationship with $\mathrm{Zn}$ concentration. The correlation analysis indicated that soybean yield had positive relationship with $\mathrm{B}$ and $\mathrm{K}$ contents of seeds in both years, while yield had significant positive relationship with $\mathrm{Ca}, \mathrm{Fe}$ and $\mathrm{P}$ concentrations of seeds.

Table 7. Correlation coefficients between traits investigated in 2012 and 2013

\begin{tabular}{c|c|c|c|c|c|c}
\hline \multirow{2}{*}{$\begin{array}{c}\text { Investigation } \\
\text { features }\end{array}$} & \multicolumn{3}{|c|}{$\mathbf{2 0 1 2}$} & \multicolumn{3}{c}{$\mathbf{2 0 1 3}$} \\
\cline { 2 - 6 } & Yield & Fat ratio & Protein ratio & Yield & Fate ratio & Protein ratio \\
\hline Fat ratio & -0.327 & & & 0.076 & & \\
Protein ratio & -0.094 & $-0.364^{*}$ & & 0.051 & $-0.552^{* *}$ & \\
$\mathrm{~B}$ & 0.228 & -0.301 & 0.166 & 0.115 & 0.088 & -0.109 \\
$\mathrm{Ca}$ & -0.152 & 0.010 & -0.071 & -0.08 & $-0.391^{*}$ & 0.325 \\
$\mathrm{Cu}$ & $-0.374^{*}$ & 0.287 & -0.215 & 0.097 & -0.006 & -0.01 \\
$\mathrm{Fe}$ & $-0.493^{* *}$ & 0.263 & -0.021 & -0.081 & $-0.361^{*}$ & 0.147 \\
$\mathrm{~K}$ & $0.506^{* *}$ & -0.162 & -0.085 & 0.013 & -0.181 & -0.028 \\
$\mathrm{Mg}$ & -0.310 & $0.353^{*}$ & -0.020 & 0.076 & -0.157 & 0.095 \\
$\mathrm{Mn}$ & -0.197 & 0.078 & 0.173 & 0.013 & -0.103 & 0.245 \\
$\mathrm{Na}$ & 0.136 & $-0.425^{*}$ & 0.272 & -0.159 & -0.158 & 0.23 \\
$\mathrm{P}$ & -0.0429 & 0.0920 & 0.0314 & -0.095 & -0.322 & 0.114 \\
$\mathrm{Zn}$ & 0.3254 & -0.1690 & 0.2327 & -0.769 & -0.225 & -0.047 \\
\hline
\end{tabular}

**Correlation is significant at the 0.01 level; * Correlation is significant at the 0.05 level

\section{Relationship between micronutrient contents of soybean seeds and fat and protein ratios}

The relationship between fat ratio and $\mathrm{Na}, \mathrm{B}, \mathrm{K}$ and $\mathrm{Zn}$ contents in 2012 was negative, which was only statistically significant for $\mathrm{Na}$ content. In contrast, correlations between fat ratio and $\mathrm{Ca}, \mathrm{Cu}, \mathrm{Fe}, \mathrm{K}, \mathrm{Mg}, \mathrm{Mn}, \mathrm{Na}, \mathrm{P}$ and $\mathrm{Zn}$ concentrations were positive, which was only statistically significant for $\mathrm{Mg}$ content. Positive correlation between fat ratio and $\mathrm{Mg}$ content indicated that increasing $\mathrm{Mg}$ content in soybean seed favors the fat accumulation in seed. The relationship between fat ratio and $\mathrm{Ca}, \mathrm{Cu}, \mathrm{Fe}, \mathrm{K}, \mathrm{Mg}, \mathrm{Mn}, \mathrm{Na}, \mathrm{P}$ and $\mathrm{Zn}$ contents in the second year was negative, which was statistically significant for $\mathrm{Ca}$ and $\mathrm{Fe}$ contents. Fat ratio had positive relationship between $\mathrm{B}$ content in the second year and the relationship was not statistically significant. 
The relationships between protein ratio and micronutrient contents of soybean seeds were not statistically significant in both 2012 and 2013. Protein ratio had positive relationship with $\mathrm{B}, \mathrm{Mn}$ and $\mathrm{Na}$ in the first year and negative relationship with $\mathrm{Ca}, \mathrm{Cu}$, $\mathrm{Fe}, \mathrm{K}$ and $\mathrm{Mg}$ contents. In the second year of the study, non-significant positive relationship was obtained between protein ratio and $\mathrm{Ca}, \mathrm{Fe}, \mathrm{Mg}$ and $\mathrm{Mn}$ contents, while the relationship was negative for $\mathrm{B}, \mathrm{Cu}$ and $\mathrm{K}$ contents.

\section{Discussion}

Average seed yield obtained in the first year $\left(2492.00 \mathrm{~kg} \mathrm{ha}^{-1}\right)$ was lower than that of the second year $\left(3943.20 \mathrm{~kg} \mathrm{ha}^{-1}\right)$. Higher maximum, minimum and total temperatures during growing season (June, July, August, September) of the first year compared to the second year may cause lower seed yield in the first year (Table 3). Increasing temperature during growing season leads to water stress in soybean plants (Jumrani and Bhatia, 2018; Shah and Paulsen, 2003; Kirnak et al., 2010; Dornbos and Mullen, 1992), which has negative impact on fertilization of the flowers and also causes the flowers to fall down.

The results revealed that genetic structure of lines/varieties, temperature stress and micronutrient contents of soils have significant effects on soybean yield and micronutrient content of seeds. Significant impacts of environmental factors on chemical composition of soybean seeds in addition to genetic structures of varieties have also been reported by Jumrani and Bhatia (2018) and Shah and Paulsen (2003).

Fat ratio is also an important trait of soybean along with high yield. Differences of genotypes in response to environmental factors indicated that fat ratio of seeds was significantly affected by environmental factors in addition to the genetic characteristics. High temperatures in 2012 caused decreasing the fat ratio of seeds in addition to the decline in yield. Similar results have been reported from studies conducted to investigate the effects of environmental factors on fat ratio of soybean seeds (Piper and Boote, 1999; Wang et al., 2015).

The difference in protein ratio between years was not significant, though protein ratio obtained in the first year was higher than the second year. In contrast to yield and fat ratio, protein ratio did not respond to the changes in temperatures, and protein ratio did not change with changes in temperatures. However, negative correlation between soybean yield and protein ratio in seed indicates that protein ratio decreases as soybean yield increases. Therefore, impact of environmental factors on soybean yield indirectly affects the protein ratio of seed, which is not directly affected by the environmental factors. Similar results have also been reported by Rotundo et al. (2009) and Kumar et al. (2006).

The $\mathrm{Ca}, \mathrm{Cu}, \mathrm{Fe}, \mathrm{K}, \mathrm{Mg}, \mathrm{Na} \mathrm{P}$ and $\mathrm{Zn}$ concentrations of soybean seeds in the first year were higher than those obtained in the second year. The differences in nutrient concentrations between years indicated the effects of temperature differences on mineral compositions of seeds in addition to the yield, fat and protein ratios. Contrasting results have been reported by studies investigating the effects of temperature differences during growing period on mineral composition of seeds. Kresović et al. (2017) reported significant effect of temperature on mineral composition, while Gibson and Mullen (2001) found increases and decreases in nutrients of soybean seeds. Researchers also indicated that differences in temperatures have indirect effect on quality of food produced by using soybean (Lim et al., 1990; Gibson and Mullen, 2001). 


\section{Conclusion}

Yield, fat ratio, protein ratio and seed mineral nutrient composition of soybean seeds were determined to investigate the performances of different soybean genotypes grown under arid conditions in two different growing seasons (2012-2013). Yield, fat ratio, protein ratio and some of important mineral nutrients of soybean lines/varieties obtained in two different seasons were different from each other. Temperatures over optimum temperature requirements of soybean had negative effect on soybean yield. High temperatures had also negative impact on fat ratio which is an important quality criterion for soybean, while protein ratio was not directly affected by high temperatures. The results also revealed that micronutrient contents of soybean seeds have been affected by the increasing temperature.

Significant impact of growing conditions on yield and quality criteria of soybean indicates the necessity to develop regional varieties. Therefore, further studies under controlled climatic conditions may increase the chance of success. The adaptation studies also should be carried out to determine the appropriate varieties prior to the initiation of soybean production in a region.

Acknowledgements. This study was conducted by the supports of General Directorate of Agricultural Research and Politics affiliated to the Turkish Republic Ministry of Food, Agriculture and Livestock within the scope of Soybean Breeding Project (TAGEM/TA/09/05/01/0014). Soybean line 11 was registered as GAPSOY-16 in 2016 by the Directorate of Seed Registration and Certification Center affiliated to the Ministry of Food, Agriculture and Livestock of Turkey.

\section{REFERENCES}

[1] Arığlu, H. H. (2007): Oil Crops Production and Breeding, Textbooks (in Turkish). Publication No: A-70, Çukurova University, Offset Atelier of Faculty of Agriculture, Adana/Turkey, pp. 14-21, 49.

[2] Baydar, H., Erbaş, S. (2014): Oil Resources Science and Technology Course Book. Süleyman Demirel University, Faculty of Agriculture, Isparta/Turkey (in Turkish).

[3] Brouns, F. (2002): Soya isoflavones: a new and promising ingredient for the health foods sector. - Food Research International 35(2/3): 187-193.

[4] Çağlar, K. Ö. (1949): Soil Science. - Ankara University, Faculty of Agriculture. Publication No. 10 (in Turkish).

[5] Dornbos, D. L. Jr., Mullen, R. E. (1992): Soybean seed protein and oil contents and fatty acid composition adjustments by drought and temperature. - Journal of the American Oil Chemists Society 69(3): 228-231.

[6] FAOSTAT (2017): Food and Agriculture Organization, User's Guide: Statistics. http://www.fao.org/faostat/en/\#data/QC (accessed on 08.08.2017).

[7] Gibson, L. R., Mullen, R. E. (2001): Mineral concentrations in soybean seed produced under high day and night temperature. - Canadian Journal of Plant Science 81: 595-600.

[8] Hasanuzzaman, M., Nahar, K., Rahman, A., Mahmud, J. A., Hossain, M. S., Fujita, M. (2016): Soybean Production and Environmental Stresses. - In: Miransari, M. (ed.) Environmental Stresses in Soybean Production: Soybean Production (Vol. 2). Academic Press, New York, pp. 61-102.

[9] Hymowitz, T. Shurtleff, W. R. (2005): Debunking soybean myths and legends in the historical and popular literature. - Crop Science 45(2): 473-4.

[10] John, M. K., Chuah, H. H., Neufeld, J. H. (1975): Application of improved azomethine-H method to the determination of boron in soils and plants. - Analytical Letters 8: 559-568. 
[11] Jumrani, K, Bhatia, V. S. (2018): Impact of combined stress of high temperature and water deficit on growth and seed yield of soybean. - Physiol Mol Biol Plants 24(1): 3750 .

[12] Kacar, B., İnal, A. (2008): Plant Analysis. - Nobel Publications, Ankara (in Turkish).

[13] Kirnak, H., Dogan, E., Turkoglu, H. (2010): Effect of drip irrigation intensity on soybean seed yield and quality in the semi-arid Harran plain Turkey. - Span J Agric Res 8(4): 1208-1217.

[14] Kresović, B. Gajic, B. A., Tapanarova, A., Dugalić, G. (2017): Yield and chemical composition of soybean seed under different irrigation regimes in the Vojvodina region. Plant Soil Envir. 63(1): 34-39.

[15] Kumar, V., Rani, A., Solanki, S., Hussain, S. M. (2006): Influence of growing environment on the biochemical composition and physical characteristics of soybean seed. - J. Food Compos. Anal. 19: 188-195.

[16] Lim, B. T., de Man, J. M., de Man, L., Buzzell, R. I.,(1990): Yield and quality of tofu as affected by soybean and soymilk characteristics: calcium sulfate coagulant. - J. Food Sci 55: 1088-1111.

[17] Lindsay, W. L., Norvell, W. A. (1978). Development of a DTPA soil test for zinc, iron, manganese, and copper. - Soil Science Society of America Journal 42: 421-428.

[18] Lovati, M. R., Manzoni, C., Canavesi, A., Sirtori, M., Vaccarino, V., Marchi, M., Gaddi, G., Sirtori, C. R. (1987): Soybean protein diet increases low density lipoprotein receptor activity in mononuclear cells from hypercholesterolemic patients. - The Journal of Clinical Investigation 80(5): 1498-1502.

[19] Messina, M. J. (1999): Legumes and soybeans: overview of their nutritional profiles and health effects. - American Journal of Clinical Nutrition 70(3): 439-450.

[20] Nelson, D. W., Sommers, L. E. (1982): Total Carbon, Organic Carbon, Organic Matter. In: Page, A. L. (ed.) Methods of Soil Analysis. Part 2. Chemical and Microbiological Properties. 2nd Ed. American Society of Agronomy Inc. Madison, WI, pp. 539-579.

[21] Olsen, S. R., Cole, C. V., Watanabe, F. S., Dean, L. A.,(1954): Estimation of Available Phosphorus in Soils by Extraction with Sodium Bicarbonate. - USDA Circular No. 939, US Gov. Print. Office, Washington, D. C.

[22] Piper, E. L., Boote, K. I. (1999): Temperature and cultivar effects on soybean seed oil and protein concentration. - Journal of the American Oil Chemists' Society 76(10): 12331241.

[23] Pratt, P. F. (1965): Potassium. - In: Black, C. A. (ed.) Methods of Soil Analysis. Part 2. Chemical and Microbiological Properties. American Society of Agronomy, Inc., Madison, WI, pp. 1022-1030.

[24] Raper, C. D., Kramer, P. J. (1987): Stress Physiology. - In: Wilcox, J. R. (ed.) SoybeanImprovement, Production and Uses. ASA-CSSA-SSSA, Madison, WI, pp. 589-642.

[25] Richards, L. A. (1954): Diagnosis and Improvement of Saline and Alkaline Soils. Handbook 60. - U. S. Department of Agriculture, Washington, DC.

[26] Rotundo, J. S., Borras, L., Westgate, M. E., Orf, J. H. (2009): Relationship between assimilate supply per seed during seed filling and soybean composition. - Field Crop Res 112(1): 90-96.

[27] Shah, N. H., Paulsen, G. M. (2003): Interaction of drought and high temperature on photosynthesis and grain-filling of wheat. - Plant and Soil 257: 219-226.

[28] Singh, G., Shivakumar, B. G. (2010): The Role of Soybean in Agriculture. - In: Singh, B. (ed.) The Soybean: Botany, Production and Uses. CAB International, Oxfordshire, pp. 24-47.

[29] Sürücü, A., Mohammad, D. M., Gunal. E., Budak, M. (2018): Concentration of heavy metals in soils along three major roads of Sulaimani, Northeast Iraq. - Carpathian Journal of Earth and Environmental Sciences 13(2): 523-538. 
[30] Turkish State Meteorological Service (2017): Meteorological data information sales and presentation system. - https://mevbis.mgm.gov.tr/mevbis/ ui/index.html\#/Workspace (accessed on 08.08.2017).

[31] Uesugi, T., Yuta, F., Yamori, Y. (2002): Beneficial effects of soybean isoflavone supplementation on bone metabolism and serum lipids in postmenopausal Japanese women: a four-week study. - J Am Coll Nutr. 21: 97-102.

[32] Ülgen, N., Yurtsever, N. (1995): Türkiye Gübre ve Gübreleme Rehberi (4. Bask1). - T. C. Başbakanlık Köy Hizmetleri Genel Müdürlüğü Toprak ve Gübre Araştırma Enstitüsü Müdürlüğ̈̈ Yayınları, Genel Yayın No: 209, Teknik Yayınlar No: T.66, Ankara.

[33] USDA (2018): Oilseed: World Markets and Trade. - USDA, Washington.

[34] Wang, J., Chen, P., Wang, D., Shannon, G., Zeng, A., Orazaly, M., Wu, C. (2015): Identification and mapping of stable QTL for protein content in soybean seeds. Molecular Breeding 35(3): 92.

[35] Xiao, C. W. (2008): Health effects of soy protein and isoflavones in humans. - The Journal of Nutrition 138(6): 1244-1249. 